\title{
Mediação segundo Peirce e Latour
}

\section{Lucia Santaella' e Tarcísio Cardoso²}

\section{Resumo}

O presente artigo pretende explorar o conceito de "mediação" na obra de dois autores: Charles S. Peirce e Bruno Latour. Sem a intenção de confrontar ambas as teorias, o artigo dedica-se a uma tarefa prévia que é aquela de explicitar a natureza desse conceito na obra de cada um desses pensadores. Em Peirce, o conceito de mediação é lógico e radicalmente abstrato. Este artigo busca trilhar o caminho realizado por Peirce para alcançar o nível de abstração a que chegou, examinando as consequências des. A seguir é apresentada a proposta antropológicasociológica latouriana, destacando sua crítica aos dualismos próprios da modernidade, sua proposta para a ação dos híbridos, e a articulação de tal proposta com as noções latourianas de intermediário, mediador e actante. Tanto em Peirce como em Latour, nota-se a existência de uma dimensão não dual, que rompe, em certo sentido, com o dualismo sujeito/objeto ao instaurar o "império do meio". Fica assim evidenciada a proeminência da mediação como ação do meio. Com isso, o presente texto pretende servir de base para pesquisas sobre mediação, dada a relevância desse conceito em um mundo mergulhado em antagonismos nos quais se encontra em falta o império do meio.

\section{Palavras-chave}

Mediação; Peirce; Latour; Comunicação; Epistemologia. 


\section{Mediation according to Peirce and Latour}

\section{Lucia Santaella'e Tarcísio Cardoso²}

\section{Abstract}

This article aims to explore the concept of "mediation" in the work of two authors: Charles S. Peirce and Bruno Latour. Without the intention of confronting both theories, the article is dedicated to a previous task, which is to explain the nature of this concept in the work of each of these thinkers. In Peirce, the concept of mediation is logical and radically abstract. This article seeks to follow the path taken by Peirce to reach the level of abstraction he reached, examining the consequences of his triad - sign-object-interpretant - as an antidote against watertight binary oppositions. Next, the Latourian anthropological-sociological proposal is presented, highlighting its critique of the dualisms inherent to modernity, its proposal for the action of hybrids, and the articulation of such proposal with the Latourian notions of an intermediary, mediator, and actant. Both in Peirce and in Latour, we note the existence of a non-dual dimension, which breaks, in a sense, with the subject / object dualism when establishing the "empire of the middle". Thus, the prominence of mediation as an action of the middle is evidenced. With this, the present text intends to serve as a basis for research on mediation given the relevance of this concept in a world steeped in antagonisms in which the empire of the middle is missing.

\section{Keywords}

Mediation; Peirce; Latour; Communication; Epistemology. 
O exercício teórico torna-se prática fundamental em um mundo cada vez mais conectado, cujas distâncias se estreitam, fronteiras se dissipam e ações, em cada ponto do planeta, afetam quaisquer outros pontos. Os contextos cognitivamente desafiadores, em que as imprevisibilidades são muitas vezes incontornáveis e as diplomacias indispensáveis, exigem o cultivo de conceitos teóricos que possam fazer frente às tendências do senso comum quando ideias simplórias sobre processos complexos, vividos e sentidos, são empregadas sem que haja discernimento sobre eles. Dentre os conceitos que se revelam cruciais para o entendimento da hipercomplexidade interconectada do espaço-tempo atual, encontra-se o conceito de "mediação", que será objeto de análise do presente texto a partir da seleção de dois autores, C. S. Peirce e Bruno Latour, cujo tratamento do tema vale a pena colocar em paralelo, não obstante as diferenças na genealogia do pensamento de cada um.

Evidentemente, há outras teorias da mediação, principalmente filosóficas e socioculturais. A escolha recaiu sobre Peirce e Latour pela centralidade que o conceito apresenta na obra de ambos. Peirce desenvolveu uma teoria lógico-semiótica da mediação bastante abstrata e, por isso mesmo, capaz de produzir consequências ontológicas, epistemológicas, sociais e culturais importantes (SANTAELLA, no prelo). Já o conceito comparece em Latour especialmente devido ao seu interesse em pensar alternativas ao projeto moderno, este que, segundo o autor, pretensamente promoveu o progresso social às custas da dominação da natureza pelo homem e que, ao fim e ao cabo, acabou por promover crises sociais e naturais até redundar no que hoje se faz conhecer sob o nome de "antropoceno". Este se define como um novo período geológico da Terra resultante de mudanças provocadas pelas intensas ações humanas na geologia e na ecologia que afetam e colocam em risco a vida do planeta.

As propostas teóricas de Peirce, no campo da lógica-semiótica, e de Latour, nas associações em rede, apresentam diferenças que poderiam, para alguns, serem consideradas opositivas. Não é a intenção deste trabalho confrontar ambas as teorias, pois tal tarefa só seria possível após o exame de cada uma delas. O que este artigo visa realizar é tão somente colocar as teorias em paralelo de modo que seja possível identificar como a noção de mediação emerge na obra de cada um desses autores. Pretende-se que a apresentação de Peirce, de um lado, e de Latour, de outro, permita futuros diálogos entre ambos, de modo a fomentar uma análise crítica sobre o alcance comparativo de cada uma das teorias. A rigor, esse seria um projeto subsequente que exigiria bastante cautela para que injustiças não sejam cometidas. Por isso, pretende- 
se que a discussão que aqui será apresentada possa servir como porta de entrada para futuras comparações. Assim, por enquanto, limitamo-nos a buscar respostas para as seguintes questões: o que quer dizer mediação para cada um deles?; como cada teoria relaciona a noção de mediação com a ideia de "ação do meio"?; se mediar é estar no meio, o que estaria nas pontas?; como a noção de mediação se relaciona com a noção de tradução?.

\section{Pressupostos da mediação em Charles S. Peirce}

A noção de mediação peirciana é radicalmente abstrata, pois está expressa na sua semiótica, por ele concebida como

[...] a quase necessária, ou formal, doutrina dos signos. Ao descrever a doutrina como "quase necessária" ou formal, quero dizer que observamos os caracteres dos signos que conhecemos e, a partir dessa observação, por um processo que não me oponho a nomear de Abstração, somos levados a afirmações, eminentemente falíveis e, portanto, em certo sentido, de maneira nenhuma necessária, quanto a quais devem ser os caracteres de todos os signos usados por uma inteligência "científica", isto é, por uma inteligência capaz de aprender pela experiência. (CP $1.227[1])$

Para compreender porquê e como Peirce chegou a tal abstração é preciso realizar um retorno ao caminho que seguiu até chegar a essa noção. Ele foi um cientista apaixonado pela filosofia, cuja grande vocação estava voltada para a lógica por ele concebida como lógica das ciências, quer dizer, a lógica que está embutida nos métodos empregados pelos mais variados tipos de ciência. Para compreender esses métodos, Peirce praticou uma pluralidade de ciências, pois, para ele, isso se constituía em uma maneira de se dedicar à lógica. Entre as primeiras conclusões que Peirce extraiu dessa prática polivalente é que todo método implica formas de raciocínio e que todo raciocínio implica signos, o nome que ele deu para aquilo que costumeiramente chamamos de pensamentos e de linguagens. Em outras palavras, não há pensamento nem há raciocínio possível, nem mesmo o pensamento e a linguagem puramente matemáticos, que façam uso apenas de signos simbólicos, tais como são basicamente as palavras nas línguas naturais, os signos matemáticos, as notações musicais etc. Ademais, para determinadas necessidades e realidades, há tipos de signos que são mais apropriados do que outros. Além disso, toda manifestação sígnica, no pensamento ou nas linguagens externalizadas, seja lá de que tipo for, atualiza-se em uma mistura de tipos de signos.

Tais constatações conduziram Peirce à decisão de que o estudo dos raciocínios e 
dos métodos das ciências deveria ser precedido pelo desenvolvimento de uma ciência dos signos, de suas combinações e dos modos como os signos crescem e evoluem, algo que ele encontrou em todos os setores e atividades humanas. Contudo, antes de se dedicar ao estudo pretendido, Peirce se autoimpôs uma tarefa precedente, dar à luz uma nova lista de categorias, distintas das categorias aristotélicas, kantianas e hegelianas, com as quais não estava satisfeito porque julgava que esses filósofos, não obstante sua grandeza, não haviam sido capazes de chegar a uma lista de categorias radicalmente universais, ou seja, onipresentes em todo e qualquer fenômeno de quaisquer espécies (CP 1.186).

Depois de muita reflexão e análise, idas e vindas, emergiram suas famosas três categorias que, com o tempo, ele esvaziou de quaisquer conteúdos específicos a fim de reduzi-las aos seus sentidos puramente lógicos: primeiridade, secundidade e terceiridade. Portanto, as categorias peircianas são estritamente lógicas, uma lógica relacional criada por Peirce, a lógica monádica, a diádica e a triádica, em correspondência com as categorias. É preciso observar que, por serem abstratas e universais, portanto, no seu ponto de generalidade máxima, elas estão na base de categorias mais particulares de modo que as três categorias reaparecem nos campos diferenciados da realidade, mas com a vestimenta específica que é própria daquele campo. Por exemplo, na física, a tríade surge como acaso, lei e tendência do universo a adquirir novos hábitos. Já na psicologia, as categorias aparecem na roupagem do sentimento, ação-reação e pensamento-tempo (CP 1.354-1.400).

Para se ter uma ideia da amplitude e abertura máxima dessas categorias, em seu nível mais geral, a primeiridade ou mônada corresponde às noções de acaso, indeterminação, vagueza, indefinição, possibilidade, originalidade irresponsável e livre, espontaneidade, frescor, potencialidade, presentidade, imediaticidade, qualidade, sentimento. A secundidade ou díada é o determinado, terminado, final, objeto, correlativo, necessitado, reativo, estando ligada às noções de relação, polaridade, negação, matéria, realidade, força bruta e cega, compulsão, ação-reação, esforço-resistência, aqui e agora, oposição, efeito, ocorrência, fato, vividez, conflito, surpresa, dúvida, resultado. A terceiridade ou tríade é o meio, devir, o que está em desenvolvimento, dizendo respeito à generalidade, continuidade, crescimento, mediação, infinito, inteligência, lei, regularidade, aprendizagem, hábito, signo (CP 1.300-1.353).

A forma mais simples de terceiridade fica expressa na relação triádica que se corporifica no signo genuíno, cuja definição Peirce ensaiou dezenas de vezes na sua luta para ser compreendido, algo nada fácil de ser alcançado há mais de um século. Se 
atéhoje são encontradas dificuldades para se compreender o escopo dessas categorias e da noção de signo genuíno e quase-signo, nelas inclusa, pode-se imaginar por que Peirce não conseguia se fazer entender no seu próprio tempo. Uma vez que a terceira categoria corresponde à noção de signo genuíno, quer dizer, genuinamente triádico, ele também buscou elaborar uma noção igualmente geral e abstrata de signo e quasesigno, estes concebidos como signos diádicos e signos monádicos. Em outras palavras, ele buscou definições capazes de explicitar como signos e quase-signos agem em geral. Partindo da fenomenologia, portanto, seu objetivo dirigia-se para a construção de uma teoria geral e abstrata de "todos os tipos de signos, seus modos de significação, denotação, informação, e todas as suas propriedades e seus modos de agir" (MS 634) [2]. Trata-se, portanto, de um campo de estudo que tem por objeto quaisquer tipos de signos verbais, não-verbais e naturais, visando compreender que natureza, quais propriedades e poderes de referência os signos têm, como eles se estruturam em sistemas e processos, como funcionam, como são produzidos e utilizados e que tipos de efeitos interpretativos estão aptos a gerar em seus possíveis intérpretes.

A noção lógica e abstrata do funcionamento sígnico é relevante porque tudo que porventura possa exibir um modo de agir similar ao modo como o signo age será ipso facto um signo. Que modo de agir é esse? Para dar uma explicação por enquanto simples, o signo implica uma tríade de relações entre o signo em si mesmo, seu objeto de referência e um interpretante ou efeito provocado pelo signo em uma mente real ou potencial. Onde houver uma tal ação, lá estará o signo. Entretanto, essa definição oculta complexidades que, se levadas a sério, podem trazer consequências bem mais proveitosas quando se pretende perceber como os signos agem. Vejamos uma definição mais modalizada.

\footnotetext{
Um signo intenta representar, em parte (pelo menos), um objeto que é, portanto, num certo sentido, a causa ou determinante do signo, mesmo que o signo represente o objeto falsamente. Mas dizer que ele representa seu objeto, implica que ele afete uma mente, de tal modo que, de certa maneira, determina naquela mente algo que é mediatamente devido ao objeto. Essa determinação da qual a causa imediata ou determinante é o signo e da qual a causa mediada é o objeto pode ser chamada de interpretante. (CP 6.347)
}

Embora essa não seja a definição mais abstrata a que Peirce chegou, o nível de abstração da explanação acima já é suficiente para dar a perceber o jogo da mediação que o signo coloca em cena. Entretanto, em vez de proceder ao escrutínio de como esse jogo se dá (SANTAELLA, no prelo), é mais didático neste momento chamar atenção para o ponto do qual Peirce partiu de modo a chegar às suas definições abstratas do signo. 


\section{0 ponto de partida para a noção de mediação em Peirce}

Peirce indica-nos o caminho para o encontro de seu ponto de partida: "Não devemos começar conversando sobre ideias puras, - pensamentos vagabundos que vagueiam pelas vias públicas sem qualquer habitação humana - mas devemos começar com os homens e suas conversações” (CP 8.112).

Ele partiu, portanto, daquilo que fazemos cotidianamente, a saber, conversamos não só uns com os outros, mas muitas vezes com nós mesmos em nossos pensamentos, o que só vem demonstrar, como queriam Platão e, também, Peirce, que todo pensamento é dialógico, um embrião de sua natureza social. Entretanto, se Peirce tivesse parado aí, esse modelo tomado em si mesmo seria muito estreito, ou seja, limitado a uma conversação entre dois falantes de uma mesma língua. Infelizmente, quando o processo comunicativo é pensado, costuma-se parar nesse modelo, sem avançar para os níveis de abstração que ele enseja. Ora, Peirce buscava chegar a um modelo geral que fosse capaz de subsumir quaisquer processos sígnicos. Portanto, para acompanhar Peirce nessa empreitada precisamos fazer os exercícios de abstração que ele fez.

Em primeiro lugar temos que constatar que, a qualquer momento, em uma conversação, os signos são emitidos, de um lado, e recebidos, de outro. Esse parece ter sido o ponto de partida da semiose ou ação do signo. A esse respeito, Peirce afirma: "A ação do signo geralmente ocorre entre duas partes, o emissor e o intérprete. Mas estes não precisam ser pessoas, pois um camaleão e muitos tipos de insetos e mesmo plantas fazem suas vidas emitindo signos ou mentindo através de signos" (MS 318: 17). Além disso, emissor e receptor alternam-se, pois o que importa, no caso, é o fluxo dos signos. Por isso mesmo, emissores e receptores não são simplesmente emissores e receptores fechados em seu próprio discurso, uma vez que o fluxo de signos está sempre prenhe de vozes, ecos de discursos de outros.

Assim sendo, os passos da abstração a serem dados implicam, em primeiro lugar, transpor a figura da mensagem, ou daquilo que é enunciado, para o termo técnico "signo". Então implicam igualmente elevar a noção do emissor para aquela do objeto do signo e a noção do receptor para a noção bem mais ampla do interpretante, ou seja, a tradução que se dá, na mente de um intérprete, do signo recebido em outro signo. Isso é inevitável, pois nossa mente funciona como uma máquina tradutória. Ao recebermos um signo, ele é, sem ou com esforço, traduzido em outro signo, tradução que sempre depende do repertório de signos-informações prévias com que estamos munidos. Vem daí a afirmação de que o significado de um signo é outro signo que, na 
semiose, corresponde ao processo tradutório que ocorre na mente do intérprete tão logo o signo chegue até ele. Dessa forma, "eu respondo, o significado de um signo é o signo para o qual ele deve ser traduzido (CP 4.132).

Como se podever, a relação básica entre objeto, signo e interpretante foi derivada da ideia de emissor, enunciado e intérprete, através de um método analítico abstrativo que Peirce caracterizou como uma busca pelos ingredientes essenciais desses três elementos presentes em todo diálogo (PEIRCE [MS 318: 52-79] apud RANSDELL, 1977, p. 172). Isso quer dizer, não custa repetir, que a famosa tríade da semiose é uma extração, em nível de abstração máxima, dos três elementos fundamentais de todo processo comunicativo. Em outras palavras, 1. signo - 2. objeto - 3. interpretante é a tríade na qual a tríade do emissor-enunciado-intérprete se transformou quando esta última foi abstraída até atingir a sua essência lógica. A pretensão de Peirce foi abstrair do emissor e do intérprete os ingredientes que são vitais à noção triádica do signo. Desse modo, o ato comunicativo ou interativo comum foi tomado como um caso paradigmático da ação sígnica, do qual seria possível extrair os componentes nucleares dessa ação (BERGMAN, 2004, p. 11).

Retomando, o termo técnico "signo" é derivado da noção logicamente mais crua de "enunciado", a noção de "objeto" é uma extração lógica do "emissor" e a noção de "interpretante" é um refinamento lógico da noção de "intérprete". Disso resultou a definição lógica, abstrata de signo:

\footnotetext{
Um signo é qualquer coisa que é de um tal modo determinada por uma outra coisa que é capaz de determinar um efeito sobre uma pessoa, efeito este que chamo de seu interpretante, este último sendo, por consequência, mediatamente determinado pelo primeiro. (NEM 3, p. 886) [3]
}

Observe-se que o signo só age como tal, só funciona efetivamente como signo, no momento em que encontra uma mente interpretadora na qual ele passará por uma operação tradutória que o converte em outro signo. Assim, a definição peirciana do interpretante é também fruto de um refinamento lógico da noção mais crua de interpretação. Essa definição é, de fato, tão refinada que a ideia mais ou menos vaga que costumamos ter de um processo interpretativo é precisamente traduzida, na semiótica peirciana, por nada menos do que doze níveis do processo interpretativo, que foram explicitados na sua teoria dos interpretantes (SANTAELLA, 1995). De todo modo, sem entrarmos nesses detalhes tão minuciosos, o que é preciso reter é que o interpretante não se confunde com o intérprete. O interpretante é um conceito muito mais vasto, um outro signo que, para ser traduzido, precisa do intérprete, mas não se reduz a ele. Além disso, não são os interpretantes individuais que importam, mas 
aqueles que são compartilhados e entram nos jogos discursivos verbais e não verbais do coletivo.

Até aí as abstrações caminham relativamente bem. O gargalo do entendimento encontra-se na operação abstrata que substitui o emissor pelo objeto do signo. Nossa mente incuravelmente cartesiana, de um eu senhor do seu discurso, atravanca a compreensão dessa operação. Passemos por ela passo a passo: na definição abstrata da operação sígnica, a fonte da semiose se encontra no objeto do signo. É o objeto que determina o signo. É o objeto que o signo intenta representar, indicar ou sugerir. Isso não diminui o quão enigmático é considerar que o objeto é uma abstração da noção de intérprete. As explicações que Ransdell (1977) nos fornece são providenciais. Em última instância, o emissor de um signo, de qualquer fenômeno interpretável, é a realidade ela mesma, uma realidade, de resto, sempre povoada de signos. Isso é verdadeiro especialmente no caso de um falante humano, quando somos levados a pensar que é a rede sígnica da realidade que fala através do falante.

Conforme foi desenvolvido em Santaella (2020), o emissor é aquele que constrói e emite o enunciado ou signo. Ora, o objeto preenche uma função similar. Do mesmo modo que o emissor não é criado pelo signo, mas pode ser visto como a fonte do signo, também o objeto precede o signo. Entretanto, sem signos não haveria emissores, assim como não haveria nada a dizer. Isso sugere que seria mais acurado afirmar que são os signos, as linguagens que nos circundam que precedem os emissores e não o contrário. A engenhosidade lógica é aqui bastante intrincada A linguagem fala através de nós, uma constatação que retira do emissor qualquer veleidade de ser o senhor onisciente de seu discurso. A fonte da semiose não está em cada emissor, mas na linguagem, nos signos que o atravessam. Como bem explica Bergman (2004), que o objeto funcione como uma espécie de substituto abstrato de um emissor não significa que o objeto seja uma espécie de repositório com algum tipo de poder autossustentado de gerar significado. Qual, então, é o papel do emissor que, na abstração peirciana, converteu-se em objeto do signo? A explicação de Bergman sobre isso é esclarecedora:

Ou o objeto é algo bem conhecido tanto do emissor quanto do receptor em uma troca comunicativa ou ele deve, de algum modo, ser mostrado ou explicado de tal maneira que o intérprete seja capaz de determinar a sua identidade em um grau relevante (MS 318: 98). Em outras palavras, o papel semiótico do objeto não é o da enunciação no sentido da produção de sentido; o aspecto crucial do emissor que o objeto preenche é aquele de um contextualizador da semiose. Servindo como iniciador da comunicação, o emissor determina sobre o que o diálogo será. De modo similar, o objeto também delimita a ação dos signos. (BERGMAN, 2004, p. 12) 
É por isso que se pode afirmar que o objeto do signo é o contexto do signo, tudo aquilo a que o signo se aplica que, em contrapartida, o signo representa, indica ou se assemelha. Contudo, a engenhosidade não para aí, mas avança na intrincada relação que o signo mantém com o objeto. O objeto é aquilo que determina o signo. Mas o fato de determinar não o leva a funcionar como um primeiro na relação triádica. O primeiro é sempre o signo em relação ao objeto que é um segundo e o interpretante que é um terceiro. Ou seja, o contexto, sempre mais vasto e vago do que o signo, nunca vem antes do enunciado ou signo que o recorta, mas é, isto sim, representado, indicado ou sugerido pelo signo. Essa posição do signo como o primeiro na relação triádica explicita sua função mediadora entre o objeto e o interpretante. É um primeiro cuja função é mediar, fazer chegar o objeto do signo até o intérprete tradutor, em função do qual o signo será traduzido e colocado nos feixes ininterruptos de semiose de que a realidade é feita. A ação do signo, portanto, é a ação do império do meio, livrando os signos da prisão às dicotomias que ensejam falsos antagonismos e oposições extremadas.

Para que, nesses feixes sígnicos, a função mediadora do signo fique ainda mais evidente, voltemos ao ponto de partida de Peirce. Como seria possível que o objeto do signo, a linguagem e o contexto dela que falam através do emissor, chegassem até o intérprete, sem a mediação do signo? Seria evidentemente impossível, caso contrário, teríamos que fantasiar um possível processo de metempsicose. Descartado esse processo ilusório, deve ficar claro que todas as mídias, que foram se multiplicando e se diferenciando até inundar o cotidiano de nossas vidas contemporâneas, não seriam capazes de realizar suas operações mediadoras sociotécnicas se, dentro delas, não corressem as veias mediadoras dos próprios signos. Portanto, as mediações primeiras vêm dos signos, eles mesmos coletivos por sua própria natureza. As mídias são mediações tecnológicas por dentro das quais correm signos. Infelizmente, os signos e a relevância do seu papel costumam ser os eternos esquecidos, ficando retidos no ponto cego da retina, um ponto colocado na sombra, o que dificulta o entendimento do funcionamento das variadas camadas tecnológicas mediadoras das máquinas de produzir linguagem de que estamos rodeados e com as quais interagimos porque compartilhamos os signos que por elas correm.

Neste ponto, deve ter ficado explicitado por que Peirce levou a tríade mais crua do emissor, mensagem e receptor a um constructo altamente abstrato. Foi para nos livrar da ilusão exclusivista de que conversações só poderiam ocorrer entre humanos e humanos. Ao contrário, a noção abstrata do signo permite-nos perceber que as conversações vão bem além ou ficam aquém desse enquadre. Elas também podem se 
dar entre humanos e animais, animais e animais, humanos e máquinas, máquinas e máquinas, moléculas e moléculas, etc. Uma noção tão estendida de conversação só foi possível dada a abstração a que Peirce submeteu a noção da tríade sígnica. Além de nos livrar das velhas dicotomias entre humano vs não humano, natureza vc cultura, natural vs artificial, etc., também nos livra da pretensão exclusivista do humano acerca da inteligência e da cognição. De fato, a generalidade abstrata a que Peirce chegou é tão radical que nos permite pensar até mesmo em interações moleculares como processos de semiose e, consequentemente, como processos comunicativos. Igualmente nos permite pensar como resolvendo-se em signos a inteligência das máquinas, das plantas, das bactérias e dos vírus, temas que recentemente estão sendo colocados em pauta de pesquisa tendo em vista a descentralização da arrogante posição do humano na biosfera.

\section{Pressupostos da mediação em Latour}

Diferentemente da tradição da lógica, concebida como lógica da ciência, à qual se vincula a epistemologia de Peirce, Bruno Latour toma a epistemologia a partir da tradição sociológica. Por partir originalmente do chamado programa forte de sociologia da ciência, que ficou internacionalmente conhecido pela expressão science studies, as teorias que Latour propõe entendem a própria noção de epistemologia como um purismo moderno que deveria, a seu ver, ser substituído pela expressão “epistemologia política”, já que este seria um dos amálgamas indissociáveis da sua crítica à ideia de "modernidade oficial". Desse ponto de vista, o que comumente se chama de epistemologia seria o terreno das controvérsias em torno da elaboração de conhecimentos pelas vias da ciência, ela própria não isenta de disputas próprias da esfera social. Nisto, os adeptos não só dos estudos da ciência, mas também dos estudos genealógicos foucaultianos e dos estudos do discurso, tomam a própria ciência como instituição, devendo, portanto, ser estudada sociologicamente.

Na prática, no entanto, a proposta latouriana opera tanto antropológica quanto sociologicamente. Se, para Latour, a antropologia parece ser o campo privilegiado para se entender a complexidade da questão da mediação, isso se deve especialmente ao legado da diplomacia da etnometodologia, interessada no diálogo da cultura com diferentes sistemas simbólicos. Isto faz, aliás, com que Latour advogue em prol de sua proposta "relacionista" (LATOUR, 1994, p. 111), que pretende atuar na "negociação" de conflitos entre realistas e construtivistas (LATOUR, 2019, p. 23). Para a discussão que se segue, portanto, é importante ter em mente essa posição antropológica-sociológica de 
Latour, pois ela vai ensejar uma proposta muito peculiar para o conceito de mediação. A seguir, apresentaremos como esse conceito vai se constituindo a partir da crítica aos modernos dos anos 1990 e como constitui uma sociologia das associações, até propor a ontogênese das entidades do social e da natureza.

\section{Contra os purismos dualistas}

A noção de mediação, em Latour, nasce no contexto da sua crítica à tendência dualista e purificadora do projeto moderno oficial, isto é, àtendência aver os fenômenos a partir de dicotomias estanques e fixadas de antemão - tais como sociedade/natureza, sujeito/objeto, mente/matéria. A crítica, que Nietszche e Foucault já tinham feito ao projeto iluminista, avançou com Latour quando este considera que tal projeto fracassa porque, paradoxalmente, o esquema dualista é, ele próprio, gerador de híbridos, isto é, de misturas. Aideia de mediação, neste contexto, surge como caminho de superação desse esquema moderno e que permite o reconhecimento e a inclusão daquilo de que a modernidade nunca conseguiu dar conta, isto é, a dimensão dos híbridos, as ações do império do meio.

Para completar o cenário moderno, Latour elabora uma tensão gráfica entre polaridade moderna oficial, isto é, a purificação que separa natureza de sociedade, e outro eixo a ser adicionado para caracterizar a ação dos quase-sujeitos e quase-objetos, isto é, daquelas entidades que não estão em nenhuma polaridade da modernidade oficial, mas que são por ela escondidas, sendo chamadas por isso de modernidade oficiosa. A dimensão criada da "não modernidade" consegue dar conta de expressar o que Latour chama de "multiplicação dos híbridos". O intuito de alcançar um esquema mais completo que o da modernidade leva Latour a propor que sejam incluídas novas "práticas", como gosta de chamar. E que novas práticas seriam estas a serem incluídas no esquema moderno? A prática do caldo misturado, isto é, daquilo que não está em nenhuma das extremidades, mas que compõe a ambas. Como diz Latour: "à prática de purificação [...] convém acrescentar as práticas de mediação” (LATOUR, 1994, p. 43).

Podemos perceber que a proposta latouriana é partir da simultaneidade de um híbrido (social-natural) para identificar modos de emergência de formas de coletivos heterogêneos. Assim, sociedade e natureza seriam coletividades (composição de entes) que surgiriam no final de um processo, seriam aquilo que resulta dos híbridos, mas apenas por seus agenciamentos. Natureza, neste sentido, precisa ser vista como a realidade que o homem moderno tentou conhecer e dominar pelo viés da 
objetividade e da cientificidade; mas também, e simultaneamente, a realidade política que o homem moderno pretendeu separar da realidade natural, como se as ciências da natureza e as sociais não tivessem uma base comum.

Sociedade, por sua vez, seria um termo impreciso para expressar a entidade coletiva caracterizada por um sistema de forças em ação a compor de modo heterogêneo uma rede de humanos e não humanos, que também foram separados no projeto moderno, mas que, para Latour, são ambos considerados atores, isto é, existentes com poder de agência. Desse modo, separar a objetividade da subjetividade, naturalizar ou sociologizar o mundo é o que o moderno sempre tentou fazer e sempre fracassou. Mais que isso, é justamente esse fracasso que acarreta o fato de que o progresso e a emancipação prometidos pela modernidade nunca pudessem ser alcançados. A mesma cisão moderna foi o que, na visão de Latour, impediu que fosse identificado que chegamos a um contexto histórico no qual a própria modernidade e o esquematismo que lhe é próprio tornaram-se incompreensíveis, tornando o mundo, aos olhos do moderno, igualmente incompreensível.

O esquematismo da modernidade oficial e sua poderosa condição dualista impede que se enxergue grande parte dos fenômenos que ele próprio causa. Esses fenômenos, pertencentes desde sempre a uma dimensão oficiosa da modernidade, justamente por terem sido obscurecidos e ocultados, saltam, para Latour, aos olhos diante das crises climáticas, dos problemas globais da ecologia, e mesmo do avanço das pandemias como a do coronavírus, uma vez que tais tipos de fenômenos são sempre simultaneamente sociais e naturais. Na leitura latouriana, isto significa que para estudar os modos de se produzir conhecimento sobre o mundo na contemporaneidade é preciso, antes de tudo, coletar e dialogar com os produtos inadvertidos da própria empreitada moderna, a saber, as misturas do social-natural.

Articulados em rede, tais "quase objetos" são indistinguíveis a priori, mas, segundo Latour, são distinguíveis a posteriori, desde que sejamos capazes de rastrear e descrever, tal como o faz a etnometodologia, sem purificar, mas deixando os atores agirem e identificando rastros nas suas ações. Se o método da antropologia empírica, míope, descritiva e rastreadora for a base epistemológica, isto significa que, para Latour, quanto mais se pensa a partir das dicotomias modernas, mais se promove o aparecimento de fenômenos híbridos não passíveis de serem conhecidos pelos esquemas. Nas palavras do autor, "quanto mais nos proibimos de pensar os híbridos, mais seu cruzamento se torna possível” (LATOUR, 1994, p. 16-17). 


\section{Mediação como império do meio}

A ação do que é meio, a mediação, corresponde, no pensamento latouriano, a um acoplamento, uma vinculação, um agenciamento que altera a própria rede, permitindo ao antropólogo/epistemólogo conhecer as forças que atuam na formação dos coletivos. Ao invés de partir de um entendimento de mundo baseado em dualismos modernos, em categorias opostas como natureza/sociedade, a proposta de Latour subverte tais classes e instaura uma empiria rastreadora míope, o que, em certo sentido, se traduz em um dilema para as formas de entendimento do projeto iluminista, deformando as categorias modernas.

Do ponto de vista sociológico, essa subversão das bases do iluminismo tem como consequência uma forma nova de fazer ciência do social, expressa no início dos anos 2000 por Latour e seus aliados como Michel Callon e John Law, no que ficou conhecido como teoria ator-rede (TAR). Em Reagregando o social (LATOUR, 2012), a base metodológica e epistemológica da TAR é detalhada. Simplificadamente, podemos dizer que tal proposta significa, simultaneamente, tomar o social como o resultado, como a rede constituída a partir de seus agenciamentos e controvérsias; e tomar a ação social a partir de uma multiplicidade de atores, tanto humanos quanto não humanos.

Apesar de ter recentemente revisto o que, na sua nova leitura, Latour (2019, p. 64) identifica como um caráter maquiavélico na própria TAR, a teoria que lhe substitui salva as duas qualidades mais fundamentais da ideia de ator-rede: a dissolução da noção de instituição para frisar que ela deveria dar conta dos não humanos; e a transformação da noção de social, que passa a ser entendida mais como "livre associação" do que como "sociedade”. Em Investigações sobre os modos de existência (2019), Latour apresenta o modo rede (cuja notação técnica é [RES]) a partir da associação entre as cadeias de referência e os móveis imutáveis (LATOUR, 2019, p. 73), isto é, a partir do reconhecimento de trajetórias de actantes e das formas novas pelas quais um coletivo permanece (em que a própria ideia de permanência não significa, nesta teoria, "permanecer o mesmo").

É daideia de socius, do latim, que diz respeito tanto ao social quanto à associação, que Latour se diferencia das teorias clássicas, que tomam a sociedade como a união de sujeitos humanos em instituições, principalmente a partir do conceito de associação, enfatizando o gesto de "se tornar sócio de", "se associar a”, o que destaca a mistura de heterogêneos, e não à forma já dada de uma instituição própria de uma sociedade.

Uma vez entendida a proposta sociológica de revisar a própria noção de "social” 
para incluir atores humanos e não humanos, Latour começa a notar que os atores de uma rede podem atuar de dois modos. Um dos modos é agir tendo em vista uma função específica, bem definida, sem alterar os fluxos nessa rede. Outro modo de agir é alterando a própria configuração da rede. Em Reagregando o social (2012), Latour chamou o primeiro de mediador e o segundo de intermediário, ambos compondo a ideia de mediação.

\begin{abstract}
Um intermediário, em meu léxico, é aquilo que transporta significado ou força sem transformá-los: definir o que entra já define o que sai. Para todos os propósitos práticos, um intermediário pode ser considerado não apenas como uma caixa-preta, mas uma caixa-preta que funciona como uma unidade, embora internamente seja feita de várias partes. Os mediadores, por seu turno, não podem ser contados como apenas um, eles podem valer por um, por nenhuma, por várias ou uma infinidade. O que entra neles nunca define exatamente o que sai; sua especificidade precisa ser levada em conta todas as vezes. Os mediadores transformam, traduzem, distorcem e modificam o significado ou os elementos que supostamente veiculam. (LATOUR, 2012, p. 65)
\end{abstract}

Nessa passagem, vemos que, enquanto os intermediários realizam um transporte cego e imparcial de uma informação, como instrumento para objetivos despropositados, os mediadores sempre operam modificações na sua correspondência com outros actantes - atores que são quase-sujeitos ou quase-objetos -, pois são entidades que alteram o curso dos dados na rede.

Diferentemente do modelo causal linear, o mediador é justamente aquele que altera os fluxos esperados, de modo que os dados de entrada não determinam perfeitamente os de saída. Essa força transformadora da rede, isto é, a plasticidade que faz frente à cristalização do coletivo sempre faz surgir coisas estranhas no meio do caminho, de modo que há, em redes de mediadores, menos previsibilidade nas ações em rede, pois não existe apenas um único efeito esperado e previamente calculado (LATOUR, 2012, p. 92). Apesar de, no que diz respeito aos mediadores, não existir causa linear na abertura dos agenciamentos, uma espécie de causação múltipla rizomática e não linear pode existir, e é essa multicausalidade que só pode ser revelada por um procedimento metodológico de rastrear, de modo a ir revelando, no decorrer dos agrupamentos recrutados, novas montagens, novas redes.

A mediação assume, neste sentido, um fazer emergir de formas e entes engendrados sempre de modo a posteriori. Essa abordagem interessa de modo especial, pois permite entender o mediador (e, portanto, o actante) como um elemento operacional das mediações, isto é, aquele que reconfigura a rede em que atua. Dito de outro modo, o conceito de actante está sendo entendido como o elemento mínimo de um processo chamado mediação que, por sua vez, expressa efeitos no funcionamento 
de outros elementos de uma rede. Vale notar que o elemento mínimo de uma rede nunca está isolado. Actante é só o termo que destaca que a ação tem origens múltiplas, parte de elementos, mas tal ação não é, de todo modo, exclusiva de um singular, é sempre co-ação, no sentido de ação conjunta.

\section{Nota final}

Sem nos aventurarmos em conclusões precipitadas, parece plausível afirmar que, embora anoção de actante em Latourtenhasido extraída da semiótica greimasiana, a engenhosidade dessa noção na teoria ator-rede alcança tal complexidade que acaba por aproximá-la da ação mediadora do signo e tradutória do interpretante peirciano. Disso se pode inferir que, embora distintos, os caminhos empreendidos por Peirce e Latour devem permitir mais aproximações do que se pode, em princípio, apreender. De todo modo, é possível confiantemente concluir que, enquanto a mediação em Peirce se revela como um modelo lógico dinâmico muito geral que deve estar na base de quaisquer processos mediadores específicos, Latour coloca em cena o modo como a mediação age, nas associações entre humanos e não humanos, por meio da performance executada pelos intermediários e mediadores. Longe de serem antagônicas, ambas as teorias se comprovam complementares. Os dados foram lançados. Mas os detalhes dessa complementaridade entregamos para trabalhos futuros.

\section{Notas}

[1] No presente texto usaremos CP para nos referirmos à obra The Collected Papers of Charles Sanders Peirce (Peirce, 1978), seguindo o padrão internacionalmente adotado pela comunidade de estudiosos em Peirce. Neste padrão, o primeiro número (antes do ponto) se refere ao Volume da referida obra, e o segundo (depois do ponto) ao parágrafo. Assim, CP 5.213 se refere ao parágrafo 213 do volume 5 dos Collected Papers.

[2] No presente texto, adotamos a notação MS para nos referirmos aos manuscritos não publicados de Peirce (PEIRCE, s/d), catalogados segundo paginação do Institute for Studies in Pragmaticism (Texas), em que o número que vem após a sigla MS refere-se ao manuscrito em questão. Quando houver página, a mesma será informada após os dois pontos (“:”), de modo que a notação MS 318: 17 refere-se à página 17 do manuscrito 318.

[3] No presente texto usaremos NEM para nos referirmos à obra The New Elements of Mathematics (PEIRCE, 1976), de modo que o número que vem logo após a sigla NEM se refira ao Volume da referida obra. A página permanecerá com a notação "p." seguida do número da página. 


\section{Referências}

BERGMAN, Mats. Fields of signification. Explorations in Charles S. Peirce's theory of signs. Philosophical Studies from the University of Helsinki 6, 2004.

FREIRE, Letícia de Luna. A ciência em ação de Bruno Latour. Cadernos IHU ideias, [s. l.], v. 1, n. 192, 2013.

LATOUR, Bruno. Jamais fomos modernos. São Paulo: Editora 34, 1994.

LATOUR, Bruno. Reagregando o Social: uma introdução à teoria do ator-rede. Salvador: Edufba, 2012.

LATOUR, Bruno. Investigação sobre os modos de existência: uma antropologia dos modernos. Petrópolis: Vozes, 2019.

PEIRCE, Charles S. The Collected Papers of Charles Sanders Peirce. Vols. 1-6, Hartshorne and Weiss (eds.); vols. 7-8, Burks.(ed.) Cambridge, Mass.: Harvard University Press, 1931-58. [Referida como CP]

PEIRCE, Charles S. Manuscripts. Institute for Studies in Pragmaticism. Lubbock: Texas, s/d. [Referida como MS]

PEIRCE, Charles S. The new elements of mathematics. EISELE, Carolyn (ed.). Berlim: Mouton de Gruyter, 1976. [Referida como NEM]

RANSDELL, Joseph. Some leading ideas of Peirce's semiotic. In: Semiotica, v. 19, n. 3/4, p. 157-178, 1977 .

SANTAELLA, Lucia. Signo é mediação. In: PEREZ, Clotilde; Trindade, Eneus (orgs.). Mediações. São Paulo: Estação das Letras e Cores Ed. No prelo.

SANTAELLA, Lucia. Charles Sanders Peirce. São Paulo: Paulus, 2020. 